\title{
More on Problems in Indonesian-Polish Contrastive Phraseology
}

\author{
Przemysław Wiatrowski \\ Adam Mickiewicz University in Poznań, Poland
}

\begin{abstract}
This article is theoretical in nature. Its subject matter includes selected issues in the field of Indonesian-Polish contrastive phraseology. It deals with the issue of excerption of research material, mainly from Indonesian and Polish phraseological dictionaries, and from general dictionaries to some extent. It takes note of the multiple qualitative and quantitative differences regarding dictionary notation of idioms and related problems faced by researchers of Indonesian-Polish phraseology.
\end{abstract}

Keywords: contrastive phraseology; Indonesian language; Polish language

\section{Introduction}

This article will discuss selected issues in the field of Indonesian-Polish contrastive phraseology, which has been developing in Poland for only a few years. Previous theoretical studies (Wiatrowski 2018a, 2018b) presented terminological differences between the Indonesian and Polish approaches to phraseology, as well as explanations of basic notions and differences regarding the characteristics of discrete units and proverbs within phraseology. They also drew attention to differences in the classification of fixed word combinations (presenting only the typology of discrete units based on the degree of lexicalization of their components). Due to the terminological chaos prevailing in Indonesian literature and some inconsistencies in the description of phraseological items, it was considered reasonable to use the theoretical background developed by Polish phraseology. This procedure will facilitate the comparison of the phraseological resources of the languages being studied.

This article develops some of the threads discussed in previous studies. Emphasis is placed primarily on the problems of excerption and multilevel characterization of dictionary phrasal resources.

\section{Certain problems of Indonesian-Polish contrastive phraseology}

The important problems faced by a researcher in Indonesian-Polish phraseology concern not only - as discussed in the previously mentioned articles (Wiatrowski 2018a, 2018b) - differences in terms of the terminology used, different explication of terms or varied sets of features used to define the essence of the idiom (this term is quite commonly accepted in the Indonesian literature on the subject to designate a basic unit of phraseology ${ }^{1}$ ) or a phraseological unit/phraseme (zwiazek frazeologiczny/frazeologizm - terms used among Polish scholars), but also sources of research material. It has already been pointed out that no suitable bilingual Indonesian-Polish (Polish-Indonesian) corpora have yet been created, and there are no Indonesian-Polish (Polish-Indonesian) translation series (Wiatrowski 2018a, 2018b). Given the above, a contrasting phraseologist is forced to reach for specialized phraseological dictionaries and - if necessary - general dictionaries, which note idiomatic expressions but to a limited extent. An undoubted advantage of the dictionary resources is that they consist of structures perpetuated in the language. In this way, occasional collocations appearing in the texts are excluded. The recording of a given lexical phraseme in a phraseographic work is confirmation of its phraseologization (Szerszunowicz 2011: 11; Młynarczyk 2013: 26).

In Poland, phraseological dictionaries of the Indonesian language are not widely available. There is a similar situation with general dictionaries, but only those in traditional book form. For years, there has been available an online version of the monumental

\footnotetext{
${ }^{1}$ However, the term phraseology (referring to both the set of stabilized discrete units and the linguistic discipline that studies such units) does not function in Indonesian linguistics (Wiatrowski 2018b).
} 
lexicographical work Kamus Besar Bahasa Indonesia, at https://kbbi.web.id/. A website has also been created (https://kbbi.kata.web.id/) devoted to the stratification of the lexical content of that dictionary. There one may find lists of structures taken from other languages (both from Indonesia's regional languages and from foreign languages from outside Indonesia) belonging to a specific field of knowledge, marked geographically, stylistically and pragmatically. The lexical material has also been grouped according to the parts of speech. Moreover, lists of oneword language units (lexemes) and lexical phrasemes covered by the term peribahasa (proverb) have been created. In this case, peribahasa includes all lexical phrasemes and sentences that are characterized by a constant composition of components and a specific meaning. According to the Polish approach, these are idioms (which are word combinations whose "fixed meaning is completely different from what results from the meanings of the constituents" - Lewicki, Pajdzińska 2001: 318), phrases/phraseological combinations (which constitute fixed expressions the sense of which lies in the semantic range of the semantic dominant although the entire unit is semantically irregular - Lewicki, Pajdzińska 2001: 319) and proverbs (a proverb "[...] is a short, simple, often rhyming utterance in the form of a sentence, usually metaphorical, containing some truth or wisdom based on human experience, used to describe a situation and instruction, of folk origin, characteristic for a given community and widely known in it, for centuries rooted in tradition and passed down from generation to generation" - Szpila 2003: 24).

A researcher of Indonesian phraseology, relying on phraseological studies, must look for resources for analysis both in peribahasa dictionaries (noting all types of discontinuous units, i.e. in the Polish typology - idioms, phrases/phraseological combinations, proverbs), and dictionaries of idioms/ungkapan (for the term ungkapan see Wiatrowski 2018b). The latter contain - to remain consistent with the Polish concept - idioms, phrases/phraseological combinations, and sometimes also (as in Badudu 2009b) certain proverbs.

The present author is currently in possession of the following dictionaries: Abdul Chaer, Kamus Idiom Bahasa Indonesi (1984), Abdul Chaer, Kamus Ungkapan Bahasa Indonesia (2002), Maman S. Mahayana, Nuradji, Totok Suhardiyanto, Kamus Ungkapan Bahasa Indonesia (1997), K.St. Pamuntjak, N.St. Iskandar, A.Dt. Madjoindo, Peribahasa (2004), Suprapto, Kamus Peribahasa Bahasa Indonesia (2007), Surayin, Dwi Nugroho, Kamus Ungkapan Bahasa Indonesia (2007), Jusuf S. Badudu, Kamus Peribahasa. Memahami Arti dan Kiasan Peribahasa, Pepatah, dan Ungkapan (2009a), Jusuf S. Badudu, Kamus Ungkapan Bahasa Indonesia (2009b), and Ariawan Prasetyo, Super Lengkap Peribahasa Indonesia Plus Update EYD Terbaru (2010). The Indonesian Internet dictionary (Kamus Besar Bahasa Indonesia) and the list of 1,898 proverbs (peribahasa) posted on the website https://kbbi.kata.web.id/ are also taken into account.

The Indonesian research material is juxtaposed with Polish idiomatic expressions and proverbs (see Nowakowska 2005 on the relationship between these terms; Wiatrowski 2018a, 2018b) taken from several lexicographical studies. So far, the following specialist dictionaries have been subjected to excerption: Stanisław Skorupka, Stownik frazeologiczny języka polskiego [Phraseological Dictionary of the Polish Language] (1967), Stanisław Bąba, Jarosław Liberek, Słownik frazeologiczny współczesnej polszczyzny [Phraseological Dictionary of Contemporary Polish] (2001), Wielki stownik frazeologiczny PWN z przystowiami [The Great Phraseological Dictionary PWN with Proverbs] compiled by Anna Kłosińska, Elżbieta Sobol, Anna Stankiewicz (Kłosińska, Sobol, Stankiewicz, comp. 2005), Mirosław Bańko, Stownik porównań [Comparative Dictionary] (2007), Stownik frazeologiczny [Phraseological Dictionary] edited by Alicja Nowakowska (Nowakowska, 2007), Maciej Czeszewski, Katarzyna Foremniak Ludzie i miejsca w języku. Stownik frazeologizmów eponimicznych [People and Places in Language. Dictionary of Eponymic Phrasemes] (2011). General dictionaries have also been used, for example: Uniwersalny słownik języka polskiego [General Polish Language Dictionary] edited by Stanisław Dubisz (Dubisz ed. 2008) and Wielki słownik języka polskiego [Great Polish Language Dictionary] edited by Piotr Żmigrodzki (http://www.wsjp.pl/). It should be noted that in some phraseological dictionaries of the Polish language (and also general dictionaries) - as in some Indonesian ungkapan dictionaries - proverbs are also recorded, but always with 
appropriate information as to which linguistic unit is concerned. There is therefore a clear lexicographic boundary between proverbs and other discrete units.

Noteworthy is the absence of the largest study of this type by Piotr MüldnerNieckowski (2003) from the list of Polish phraseological dictionaries. This dictionary was excluded from the analysis due to the quite numerous and fundamental reservations as to lexicographic technique that have been expressed with regard to this work (IgnatowiczSkowrońska 2003; Dziamska-Lenart 2010).

A comparison of Indonesian and Polish dictionaries containing stabilized colocations (also proverbs) shows significant differences that affect the work of a contrasting phraseologist. First of all, no Indonesian phraseological dictionaries have yet been compiled (and the abovementioned Polish dictionary edited by Alicja Nowakowska - Nowakowska 2007 - is such a work). Secondly, no dictionary of eponymous phrasemes has been created. Thirdly, there is also no Indonesian dictionary containing only phraseological comparisons. It should be recalled that Indonesian linguistics misconstrues these as a subset of narrowly defined proverbs (Wiatrowski 2018a, 2018b). The availability of parallel dictionaries of such types (i.e. present in Indonesian and Polish lexicographies) would allow a comparison of research material to be made using different levels of confrontation.

What is more important, however, is the issue concerning the count of the juxtaposed phraseological sets. The largest dictionary in this respect is the dictionary of idioms by Abdul Chaer (1984), which includes more than 5,200 language units in the form of single words (these are only 5 of these) and discrete units being idioms and compositional phrasemes. The Suprapto 2007 study includes 4,444 language units (proverbs, idioms and compositional phrasemes). Slightly smaller is the Pamuntjak, Iskandar, Madjoindo 2004 dictionary, with 4,032 units (proverbs, idioms and compositional phrasemes). On the other hand, the ungkapan dictionary by Jusufa S. Badudu (2009b) includes 3559 entries, but there are over 900 single-word units in this set. Other language units include idioms, compositional phrasemes and selected proverbs.

In quantitative terms, the Polish phraseological studies are much superior. For example, the Skorupka 1967 dictionary includes 80,000 phrasemes, the Kłosińska, Sobol, and Stankiewicz 2005 dictionary includes about 17,000 phraseological units, while the Bąba, Liberek 2001 work has about 4,000. It should again be emphasized that the above-mentioned dictionaries record predominantly idioms and phrases/phraseological combinations. Proverbs are, to some extent, an additional element (there are separate studies collecting proverbs in Poland). Proverbs are not included in the Bąba, Liberek 2001 dictionary. Such quantitative disparities result, among other things, from the fact that Indonesian lexicographers need to take tradition into account. They refer to the earliest phraseological dictionaries, rely on the material contained there, and supplement the recorded linguistic units with new phrasemes only to a minor extent. In addition, lexical phrasemes that are no longer used are not removed.

The greatest difficulty for phraseologies comparing Indonesian and Polish fixed collocations excerpted from dictionaries is the absence of invaluable data from the Indonesian lexicographic studies. One should mention in this regard the shortage of grammatical information concerning the valence properties of the entry units, failure to note the phenomenon of multilogy of lexical phrasemes, and the fact that contexts of usage are given only for selected language units and to a minimal degree.

Particular attention should be paid to the absence of pragmatic information, showing the conditioning of discrete units by the style varieties of the Indonesian language, and indicating their expressive nature. This lack is particularly acute when phraseological resources of the languages being studied are confronted in order to detect equivalents. There follow just a few examples of Indonesian expressive compounds whose (stylistic, pragmatic and other) undertones are not reflected in lexicographical studies: dilindungi dewa fortuna (lit. protected by the goddess Fortune) 'be lucky' - a mythologist borrowed from European languages; asrama prodeo (lit. a free-of-charge dorm) 'prison' - a euphemism; indak mati oleh Belanda (lit. he did not die because of the Netherlands) 'invincible, indestructible' - a recessive phraseme. 
It is extremely interesting that the studied dictionaries do not record vulgar, slang or colloquial collocations, for example: main karaoke (lit. to play karaoke) 'to have oral sex with someone' - a discrete unit with vulgar undertone; si adik (lit. younger brother) 'penis' - a slang expression; gadis yang berbau bensin (lit. a girl who stinks of gasoline) 'a girl interested in expensive cars and other luxury goods' - a phraseological colloquialism.

The style and pragmatic parameters are - alongside the meaning, formal structure or image - an important factor influencing the relation of equivalence between the juxtaposed language units. This is shown, for example, by the Indonesian-Polish pair of sudah makan bismillah (lit. to have already eaten, in the name of Allah) 'to do something in the wrong order, contrary to the rules' - and od dupy strony (lit. from the arse side) 'incorrectly, in the reverse order'. The Polish equivalent is characterized by a very high degree of semantic similarity to the Indonesian phraseme, but at the same time a different formal structure and pictoriality. Were only these factors to be taken into account, one could consider the Polish construction as a functional equivalent of the Indonesian idiom (for information on the concept of equivalence used here, see Chlebda, 2011). However, this is not possible in view of the stylistic incommensurability between the compared phrasemes. This is so large (the neutral Indonesian construction contains the theonym included in the bismillah invocation formula; the Polish construction is a vulgar phrase) that this equivalent ought to be classified as a dubious translation. Similar problems have often appeared in works on the equivalence of IndonesianPolish discrete units (Wiatrowski 2014, 2015b, 2015c, 2015d, 2015e, 2015f, 2016).

It should be added here that, in principle, none of the Indonesian phraseological dictionaries available to the author of this article include qualifiers. A reader interested in the subject cannot, therefore, check whether the given phraseme carries a certain undertone characteristic of certain language varieties used in specific communication or in a specific territory. A rudimentary form of qualifiers is exclusively present in Pamuntjak, Iskandar, Madjoindo, 2004. The gaps in lexicographic qualifications are filled to a certain extent by the data contained in the Kamus Besar Bahasa Indonesia. The absence of appropriate qualifiers in the Indonesian phraseological dictionaries obliges researchers to refer to their own language and communication skills. On the other hand, Polish dictionary qualification - though imperfect (the qualifiers used by lexicographers usually do not constitute a logical and disjunctive system; they are not always consistently applied) - is much better developed. It supplies data on the terminological nature of linguistic units, their stylistic-pragmatic, socio-environmental, geographic and environmental undertones, chronological and frequency information, etc. (Żmigrodzki, 2005: 69).

\section{Conclusions}

Analysis of the theoretical issues lying within the scope of Indonesian-Polish contrastive phraseology is expected to result in findings that will constitute a theoretical and methodological background for the first bilingual dictionary of Indonesian-Polish phraseology in Poland (Wiatrowski, 2018b). The authors of this dictionary, however, have a number of different challenges to face. Before developing a coherent concept of the description of Indonesian-Polish phraseology, it is necessary to comprehensively address issues that have not yet come to the attention of Indonesian researchers. For example, there are such important problems as the grammatical and valence properties of discrete units, the phenomena of uniformity and multiformity of stabilized phrasemes, their stylistic-pragmatic undertones, and also phraseological derivation and synonymy. A detailed description of these issues is not possible without a solid corpus rich in data reflecting the Indonesian language area in a representative manner. And such an online corpus is still awaited by Indonesian linguistics.

\section{References}

Badudu, J. S. 2009a. Kamus Peribahasa. Memahami arti dan kiasan peribahasa, pepatah, dan ungkapan. Jakarta: Kompas.

Badudu, J. S. 2009b. Kamus Ungkapan Bahasa Indonesia. Jakarta: Kompas. 
Bańko, M. 2007. Stownik porównań. Warszawa: PWN.

Bąba, S. \& Liberek, J. 2001. Słownik frazeologiczny wspótczesnej polszczyzny. Warszawa: PWN.

Chaer, A. 1984. Kamus Idiom Bahasa Indonesia. Ende: Nusa Indah.

Chaer, A. 2002. Kamus Ungkapan Bahasa Indonesia. Jakarta: Rineka Cipta.

Chlebda, W. 2011. Ekwiwalencja i ekwiwalenty: między słownikiem a tekstami. In Chlebda, W (ed.). Na tropach translatów. W poszukiwaniu odpowiedników przektadowych. Opole: UO, 21-43.

Czeszewski, M. \& Foremniak, K. 2011. Ludzie i miejsca w języku. Słownik frazeologizmów eponimicznych. Warszawa: Wydawnictwa UW.

Dubisz, S. 2008. Uniwersalny słownik języka polskiego. Warszawa: PWN.

Dziamska-Lenart, G. 2010. 110 lat polskiej frazeografii. In Bąba, S., Skibski, K \& Szczyszek, M (eds.). Perspektywy wspótczesnej frazeologii polskiej. Teoria. Zagadnienia ogólne. Poznań: UAM, 163-192.

Ignatowicz-Skowrońska, J. 2003. Piotr müldner-nieckowski, wielki słownik frazeologiczny języka polskiego, świat książki, warszawa, 1088s. Studia Językoznawcze, 2, 460-472.

Kamus Besar Bahasa Indonesia, http://kbbi.web.id/. (Accessed 2014-2018).

Kłosińska, A., Sobol, E. \& Stankiewicz, A. 2005. Wielki słownik frazeologiczny PWN z przystowiami. Warszawa: PWN.

Kridalaksana, H. 1982. Kamus Linguistik. Jakarta: Gramedia Pustaka Utama.

Mahayana, M. S., Nuradji \& Suhardiyanto, T. 1997. Kamus Ungkapan Bahasa Indonesia. Jakarta: Grasindo.

Młynarczyk, E. 2013. Nie święci garnki lepia”. Obraz rzemiosta utrwalony w polskiej frazeologii. Kraków: Wydawnictwo Naukowe UP.

Müldner-Nieckowski, P. 2003. Wielki stownik frazeologiczny języka polskiego. Warszawa: Świat Książki.

Nowakowska, A. 2007. Stownik frazeologiczny. 3rd ed. Wrocław: Europa.

Nowakowska, A. 2005. Świat roślin w polskiej frazeologii. Wrocław: Uwr.

Pamuntjak, K. St., Iskandar, N. St. \& Madjoindo, A. Dt. 2004. Peribahasa. Jakarta: Balai Pustaka.

Pateda, M. 2010. Semantik Leksikal. Jakarta: Rineka Cipta.

Prasetyo, A. 2010. Super Lengkap Peribahasa Indonesia Plus Update EYD Terbaru. Yogyakarta: Cakrawala.

Skorupka, S. 1967 Słownik frazeologiczny języka polskiego, Warszawa: Wiedza Powszechna, vol. 1-2.

Suprapto. 2007. Kamus Peribahasa Bahasa Indonesia. Bandung: Mandar Maju.

Surayin \& Nugroho, D. 2007. Kamus Ungkapan Bahasa Indonesia. Bandung: Yrama Widaya.

Suyatno, M. 2012. Idiom dalam Bahasa Indonesia. Ph.D. dissertation, Universitas Gajah Mada.

Szerszunowicz, J. 2011. Obraz człowieka $w$ polskich, angielskich $i$ wtoskich leksykalnych $i$ frazeologicznych jednostkach faunicznych. Białystok: UwB.

Szpila, G. 2003. Krótko o przysłowiu. Kraków: Collegium Columbinum.

Wiatrowski, P. 2014. Jeszcze o genezie wybranych polskich i indonezyjskich jednostek frazeologicznych. Język. Komunikacja. Informacja, 9, 147-163.

Wiatrowski, P. 2015b. Ekwiwalencja słownikowa indonezyjskich i polskich idiomów. In Olchowa, G \& Balowski, M (eds.). Języki stowiańskie $w$ okresie przemian. Banská Bystrica: Univerzita Mateja Bela v Banskej Bystrici, 107-125.

Wiatrowski, P. 2015c. Indonezyjskie i polskie idiomy - w poszukiwaniu ekwiwalentów tłumaczeniowych. Poznańskie Spotkania Językoznawcze, 29, 137-158.

Wiatrowski, P. 2015d. Indonesian and Polish idioms - in search of translation equivalents. In Haroon, H., Omar, H. C., Seong, G. S., \& Ardi, N (eds.). Persidangan Penterjemahan Antarabangsa ke-15 (PPA-15). $15^{\text {th }}$ International Conference on Translation (ITC-15). Kuala Lumpur: Persatuan Penterjemah Malaysia, Institut Terjemahan \& Buku Malaysia, Dewan Bahasa dan Pustaka, Perbadanan Kota Buku, 433-442. 
Wiatrowski, P. 2015e. Międzyjęzykowa ekwiwalencja związków frazeologicznych $\mathrm{z}$ apelatywnym komponentem relewantnym kulturowo. Na przykładzie indonezyjskich połączeń wyrazowych i ich polskich odpowiedników. Kwartalnik Językoznawczy, 1-2, $62-175$.

Wiatrowski, P. 2015f. Międzyjęzykowa ekwiwalencja związków frazeologicznych $\mathrm{z}$ komponentem onimicznym. Na przykładzie indonezyjskich połączeń wyrazowych i ich polskich odpowiedników. Kwartalnik Językoznawczy, 3-4, 96-145.

Wiatrowski, P. 2016. Wilk w owczej skórze”, czyli „serigala berbulu domba”. Uwagi o genezie wybranych polskich i indonezyjskich jednostek frazeologicznych. In Dziamska-Lenart, G \& Liberek, J (eds.). Perspektywy wspótczesnej frazeologii polskiej. Geneza dawnych $i$ nowych frazeologizmów polskich. Poznań: Wydawnictwo Naukowe UAM, 185-207.

Wiatrowski, P. 2018a. Indonesian-Polish contrastive phraseology. In Yanti (ed.). KOLITA 16. Konferensi Linguistik Tahunan Atma Jaya Keenam Belas. Tingkat Internasional. Jakarta: Pusat Kajian Bahasa dan Budaya Universitas Katolik Indonesia Atma Jaya, 378-383.

Wiatrowski, P. 2018b. On some problems of Indonesian-Polish contrastive phraseology (forthcoming).

Wielki słownik języka polskiego, http://www.wsjp.pl/. (Accessed 2014-2018).

Żmigrodzki, P. 2005. Wprowadzenie do leksykografii polskiej. Katowice: UŚ. 